Gabriela Gorqca-Sawczyk

Uniwersytet im. Adama Mickiewicza w Poznaniu

\title{
RÓŻNORODNOŚĆ TECHNIK UCZENIA SIĘ SŁOWNICTWA W JĘZYKU OBCYM
}

\begin{abstract}
Variety of vocabulary learning techniques in a foreign language
In this article I will concentrate on various techniques for learning and teaching vocabulary that support the memorizing of new words, and I will present the results of a survey conducted among students of applied linguistics on this topic. The main aim of this article is to verify the hypothesis that students haven't yet been exposed to different techniques for effective vocabulary learning. First, I will show what the mental lexicon is and how it is organised. How mnemonists learn will also be discussed. Then I will briefly explain the terms 'vocabulary' and 'lexical competence' and show the important principles of vocabulary training. At the end, I will present the most important results of my survey (opinion poll).
\end{abstract}

Keywords: mental lexicon, vocabulary learning, lexical competence, memorizing, learning techniques

Słowa kluczowe: leksykon mentalny, nauka słownictwa, kompetencja leksykalna, zapamiętywanie, techniki uczenia się

\section{Wprowadzenie}

Nauka słownictwa wymaga od uczącego się zdyscyplinowania, regularnego powtarzania, dużej koncentracji uwagi oraz wytrwałości, a także kreatywnego podejścia do pracy nad nowym materiałem leksykalnym. W jaki sposób sprawić, by nauka słownictwa nie kojarzyła się ze żmudną pracą? Które techniki mogą okazać się pomocne w zapamiętywaniu nowych słów? Jak uczniowie i studenci mogą wykorzystać przy tym swoją pomysłowość? 
W artykule skoncentruję się na technikach, które wspierają zapamiętywanie słownictwa oraz przedstawię wyniki ankiety przeprowadzonej wśród studentów lingwistyki stosowanej. Celem tego artykułu jest weryfikacja hipotezy zakładającej, iż studenci, którzy nie zostali zapoznani z rozmaitymi technikami efektywnego uczenia się słownictwa i nie przećwiczyli ich podczas zajęć z języka obcego, stosują sposoby zapamiętywania, które wypracowali sobie podczas samodzielnej nauki. W pierwszej części artykułu wyjaśnię pojęcie leksykonu mentalnego. Wspomnę, jak osoby o niebywałych możliwościach pamięciowych (mnemoniści) zapamiętują nowe słowa, a następnie przybliżę definicję słownictwa, kompetencji leksykalnej oraz zaprezentuję, w jaki sposób powinna przebiegać efektywna nauka nowych słów. Po opisaniu wyników badania ankietowego przedstawię wnioski i implikacje glottodydatyczne.

\section{Leksykon mentalny}

Pisząc o nauce słownictwa w kontekście efektywnego zapamiętywania go, nie sposób pominąć leksykonu mentalnego, inaczej zwanego słownikiem umysłowym, który jest zdaniem Kurcz (2000: 106): „czymś pośrednim między słownikiem sensu stricto a encyklopedią", a ściślej „stanowi intuicyjną wiedzę na temat wyrazów danego języka, jaką mają użytkownicy tego języka". Leksykon mentalny można sobie wyobrazić jako wielopłaszczyznową i dynamiczną sieć z licznymi semantycznymi i fonetycznymi połączeniami, która jest sprzężona ze wszystkimi kanałami zmysłów (Roche, 2008: 65n.). Słownik umysłowy jest częścią pamięci długotrwałej. Podczas recepcji słowa trafiają kanałami percepcyjnymi (słuchowym i wizualnym) poprzez pamięć krótkotrwałą do pamięci długotrwałej. Podczas produkcji językowej słowa są z kolei wydobywane z pamięci długotrwałej, potem przechodzą przez pamięć krótkotrwałą, a następnie dochodzi do artykulacji lub zapisania ich. Zapamiętywanie określonego słowa przebiega dwojako. Forma i treść zapisywane są w leksykonie osobno, jednak są reprezentowane w nim blisko siebie (Neveling, 2010: 217). Leksykon mentalny mieści w sobie nie tylko wiedzę na temat posiadanego słownictwa z języka ojczystego, lecz także każdego języka obcego, którym dysponujemy, a także tego, którego się uczymy. W leksykonie mentalnym zawarte są informacje fonologiczne, morfologiczne, semantyczno-konceptualne i syntaktyczne (Handke, 1994:93). Legutko-Marszałek (2008: 72) podkreśla, że u użytkownika, który mówi biegle w danym języku, wydobywanie powyższych informacji odbywa się nieświadomie.

Jeżeli chodzi o komponenty semantyczno-syntaktyczne można wskazaćna różne modele łączenia wyrazów, zapamiętywania i przechowywania informacji 
(Stork, 2003: 71n.). Pierwszy opiera się na rozróżnieniu dwóch rodzajów cech określonych pojęć, tj. na definiujące, które zawsze towarzyszą określonemu pojęciu oraz charakterystyczne, które nie zawsze mu towarzyszą (Smith, Shoben i Rips, 1974). Na przykład przy weryfikacji wyrażenia ołówek jest przyborem szkolnym porównujemy najpierw cechy definiujące i charakterystyczne dla pojęć: „ołówek” i „przybory szkolne”. Im bardziej zgodne są ich cechy, tym łatwiej przychodzi nam zweryfikowanie informacji. Drugi model, nazywany prototypowym, został wprowadzony przez Eleonorę Rosch w 1978 roku. W tym modelu pojęcie jest reprezentowane przez prototyp, czyli przedstawiciela o najbardziej typowych cechach. I znów, jeżeli pojęcie posiada cechy podobne do prototypu, wówczas jest szybciej rozpoznawane, niż gdy ich nie posiada (np. ptak-wróbel). Problematyczna w tym modelu wydaje się polisemia, a więc wieloznaczeniowość pojęć (np. zamek). Kolejnym modelem, który służy do rozpoznawania wyrazów, jest model sieci, którego idea opiera się na siatce połączeń międzywyrazowych. W odniesieniu do tych modeli wyróżnia się z kolei dwa sposoby połączeń międzywyrazowych: hierarchiczny oraz tzw. spreading activation theory zaproponowany przez Collins i Loftus (1975), w którym chodzi o natężenie i gęstość powiązań. System opierający się na spreading activation theory bazuje na połączeniach asocjacyjnych (Neveling, 2010: 218). Proces aktywacji słów można sobie wyobrazić jako aktywowanie całej mapy myśli w każdym dostępnym kierunku.

Istotnym aspektem asocjacyjnego funkcjonowania ludzkiej pamięci jest przykładowo zapamiętywanie znaczeń rzeczowników z ich właściwościami. James Deese (1959), Henry Roediger and Kathleen McDermott (1995) stworzyli ciekawy test ${ }^{1}$ sprawdzający, w jaki sposób funkcjonuje pamięć. Autorka niniejszego artykułu prześledziła go i wypełniła. Oto na czym on polega: na monitorze pojawia się lista 15 słów, po 15 sekundach ukazują się kolejno trzy słowa ze wcześniej pokazanej listy. Trzeba odgadnąć, czy te trzy słowa znajdowały się na liście. Test wykazuje, co następuje: większość badanych sądzi, że wśród 15 słów pojawiło się słowo sweet (słodki), co jest błędną odpowiedzią. Pamięć działa na zasadzie skojarzeń, bowiem wśród 15 słów znalazło się aż 6 słów, które mają słodki smak: honey (miód), pie (placek), chocolate (czekolada), candy (cukierek), sugar (cukier). Poza tym na liście widniało jeszcze słowo taste (smak). Nagromadzenie kilku rzeczowników, które łączy słodki smak oraz słowo „smak" prawdopodobnie podsunęło bezpośrednie skojarzenie ze słowem „słodki”. To doświadczenie oparte na tzw. primingu² (czyli torowaniu),

\footnotetext{
${ }^{1}$ Zob. http://neuroscience.uth.tmc.edu/s4/chapter07.html [18.07.2014].

${ }^{2}$ Eksperymenty z zakresu primingu pokazują, że podjęcie decyzji dotyczące wyboru słowa jest przyspieszone i uwarunkowane tym, jakie słowo zostanie nam pokazane chwilę wcześniej i na ile jest ono zbliżone semantycznie (Stork, 2003: 72).
} 
pokazuje, że widząc różnego rodzaju obiekty, kojarzymy je z ich właściwościami do tego stopnia, że wydaje nam się, że owe właściwości też „zobaczyliśmy" (w tym przypadku torowanie podprogowe). Pamięć ma zatem charakter silnie asocjacyjny. W nauczaniu języków obcych często podkreśla się dziś, że uczenie się na zasadzie skojarzeń wspomaga jego efektywność.

Ponadto słownik umysłowy jest uporządkowany według 7 zasad: 1. Relacji czasowej, przestrzennej, logicznej, tematycznej między leksemami, 2. Podobieństwa semantycznego (synonimy, antonimy, polisemia), 3. Podobieństwa fonetycznego i grafemicznego (np. rymy), 4. Podobieństwa morfologicznego (np. rodziny wyrazów), 5. Hierarchii (kategorie, podkategorie), 6. Linearności (połączenia syntagmatyczne) oraz 7. Afektywności (Neveling, 2010: 217).

Osobną kwestią dyskutowaną wśród badaczy jest organizacja wielojęzycznego leksykonu mentalnego. A dokładniej, w kręgu zainteresowań naukowców znajduje się pytanie, jaka zależność istnieje między systemami reprezentacji języka pierwszego, drugiego i ewentualnie kolejnych u osób wielojęzycznych. W związku z tym powstają pytania, czy tworzą one jeden system, dwa oddzielne, działające równolegle lub są sobie w jakiś sposób podporządkowane. Niektórzy badacze: Groot (1993), Nation (1993), Lutjeharms (2004), Dong (2005) i in., Hulstijn (1997) i Paradis (2004) przypuszczają, że istnieje forma mieszana. Wyróżniają oni cztery możliwości działania leksykonu. Organizacja według systemu rozszerzonego (extended system) oznacza, że nie rozróżnia się osobnych magazynów dla każdego języka. System dualny zakłada, że każdy język jest przechowywany w osobnym magazynie. Tripartite system przyjmuje, że we wspólnym rezerwuarze przechowywane są tylko te informacje, które są podobne w różnych językach. Te pojęcia, które są typowe dla danego języka przechowywane są oddzielnie. Ostatnia hipoteza subset wychodzi od tego, że słowa w języku pierwszym, drugim, trzecim są ze sobą ściśle związane, tworząc podgrupy w jednym wspólnym systemie.

\section{Ekskurs o mnemonistach}

Informacje, które uznamy za istotne i interesujące łatwiej są przez nas zapamiętywane, przechowywane i wydobywane. Ponadto w psychologii mówi się o zjawisku pierwszeństwa i świeżości, które oznacza, że elementy występujące na początku lub na końcu wypowiedzi są przez nas lepiej zapamiętywane. Warunek znacznie ułatwiający przyswajanie i wydobywanie informacji to ich sens i zrozumiałość. Co ciekawe, badania przeprowadzane na Szereszewskim, człowieku, zdawałoby się, o nieograniczonych możliwościach pamięciowych, wykazały, że u niego zjawisko pierwszeństwa i świeżości nie miało znaczenia dla 
zapamiętywania. Szereszowski zapamiętywał słowa poprzez przywoływane obrazy, „dlatego łatwiejsze były dla niego słowa mające konkretne desygnaty obrazowe, a trudności sprawiały wyrazy abstrakcyjne lub pozbawione sensu" (Czerniawska, 2003: 82). Badania nad mózgiem wykazały, że inne ośrodki w mózgu aktywują się podczas zapamiętywania rzeczowników konkretnych i abstrakcyjnych (Müller, 2003). W przypadku rzeczowników konkretnych uaktywniają się ośrodki odpowiedzialne za różne modalności (związek z możliwymi do określenia właściwościami), natomiast przy próbach zarejestrowania i zapamiętania rzeczowników abstrakcyjnych pracowały ośrodki typowo związane z przetwarzaniem języka. W związku z tym, Müller (2003) postuluje, by także rzeczowniki abstrakcyjne starać się pokazać uczącym się języka obcego za pomocą różnych modalności (Müller, 2003: 170). Jest to zadanie trudne (jak przedstawić np. słowo Hoffnung - niem. nadzieja wizualnie?), ale warto podejmować takie próby (np. posługując się symbolami) i badać, jak to wpływa na przyswojenie tych słów.

Szereszewski był synestetykiem, tzn. jedna modalność uruchamiała u niego inną modalność. Osoby, które charakteryzuje synestezja patrząc na określone słowa lub liczby widzą kształty, kolory, słuchając określonych głosów czują faktury, smaki. To synestezja powodowała u niego, jeśli nie była kluczowa, szybkie zapamiętywanie. Według Czerniawskiej, (2003: 81n.), najważniejsze mnemotechniki stosowane przez Szereszewskiego to: wyobrażenia umysłowe, silne asocjacje i synestezje. Najbardziej znanym, obecnie żyjącym synestetykiem jest Daniel Tammet, który w krótkim czasie potrafi nauczyć się niemalże dowolnego języka obcego, o czym świadczyły wyniki eksperymentów przeprowadzonych w Niemczech i Islandii. Tammet miał nauczyć się języka niemieckiego i islandzkiego w stopniu komunikatywnym w ciągu tygodnia. Po tym czasie był w stanie w miarę swobodnie porozmawiać w tych językach ${ }^{3}$. Oczywiście, synestezja jest zjawiskiem rzadkim, niemniej pokazuje, że wielokanałowe i wielomodalne uczenie wykorzystujące rozmaite bodźce może być niezwykle efektywne.

Sygnały towarzyszące zapamiętywaniu mają znaczący wpływ na „zakotwiczenie" w pamięci nowo poznanych słów. Łatwiej będzie nam przywołać nowe słowa, gdy pojawią się te same sygnały podczas wydobywania z pamięci, które towarzyszyły nam podczas kodowania (Michońska-Stadnik, 2008). I chodzi tu nie tylko o sygnały dźwiękowe czy wzrokowe, lecz także zapachowe i dotykowe. Także przestrzeń w jakiej nauczamy ma znaczenie. Jeśli wprowadzamy

${ }^{3}$ http://www.spiegel.de/international/germany/who-needs-berlitz-british-savant-lear ns-german-in-a-week-a-611381.html DW 20.07.2014. Więcej o możliwościach językowych Tammeta można dowiedzieć się z artykułu naukowego Baron-Cohena i in. 2011. 
słowa związane z parkiem, jak np. drzewo, ławka, trawnik, krzewy itp., optymalnym byłoby wyjście na spacer do parku i pokazywanie określonych elementów tworzących krajobraz parkowy. Oczywiście jest to trudne w realizacji, niemniej warto wziąć takie podejście pod uwagę.

\section{Efektywne nauczanie i uczenie się słownictwa wspierające procesy pamięciowe}

Pod pojęciem słownictwa należy rozumieć sieć powiązanych ze sobą słów, a nie pojedyncze, wyizolowane słowa (Klippel, 1995:101). Choć ich forma i znaczenie zapamiętywane są oddzielnie, istnieją w mózgu bliskie powiązania między nimi (Huneke i Steinig, 2002:146).

Opanowanie słownictwa wiąże się ze wszystkimi subsystemami i sprawnościami językowymi, tj. uczeń zna nowe słowo, jeśli potrafi je rozpoznać, zrozumieć, wypowiedzieć, napisać i użyć w kontekście. Jednak nie tylko te aspekty składają się na kompetencję leksykalną, która jest konieczna w efektywnej komunikacji obcojęzycznej. Wychodząc od pojęcia kompetencji, która mieści w sobie zarówno wiedzę jak i umiejętności, można rzec, że kompetencja leksykalna to zasób słownictwa i wiedza na temat tego słownictwa oraz umiejętność wykorzystania tej wiedzy w sytuacji komunikacyjnej. Zatem uczeń / student nie tylko potrafi użyć danego słowa, lecz także zdaje sobie sprawę i potrafi wytłumaczyć, dlaczego owego słowa użył. Uczący się powinien nie tylko umieć powiązać słowa ze sobą, ale też uzasadnić wybór określonych słów: „manipulate words, relate them to other words and to their own experiences, and then justify their choices" (Sökmen, 1987: 242).

U Targońskiej (2011a: 122) można znaleźć rozwinięcie tej definicji o następujący aspekt: w przypadku, gdy brakuje uczniowi słowa, potrafi on zastosować strategie kompensacyjne. Ćwiczenie takich strategii uważam za istotny element nauki obcojęzycznego słownictwa.

Trudności, które napotykają uczący się języków obcych podczas przyswajania słownictwa, to m.in. zapamiętywanie i przywołanie z pamięci nowych słów (Biedroń, 2009: 29-32). Targońska (2011b: 65) zwraca uwagę na fakt, że studenci podejmujący studia neofilologiczne mają słabo rozwiniętą kompetencję leksykalną. Przyczyny tego stanu rzeczy upatruje w złych nawykach uczeniowych, wyniesionych prawdopodobnie ze szkoły, takich jak na przykład mechaniczne uczenie się wyizolowanych słów (ibidem).

Rolą nauczyciela jest zaprezentowanie uczącym się możliwych sposobów podejścia do nauki i pomoc w dobraniu najskuteczniejszej strategii: „Na każdym poziomie nauczania, kurs języka powinien umożliwić uczniom i słuchaczom 
poznanie i utrwalenie różnorodnych środków językowych, które pozwolą im na efektywne rozumienie wypowiedzi ustnych i pisemnych oraz na tworzenie własnych wypowiedzi w mowie i w piśmie, poprawnych pod względem fonetycznym, ortograficznym, leksykalnym i morfosyntaktycznym" (Gajos, 2010: 5). Aby pokazać uczniowi, jak może się uczyć, potrzebna jest nauczycielowi wiedza między innymi z zakresu przebiegu procesów zapamiętywania i przypominania nowo poznanych słów.

Już w 1995 roku, w swojej publikacji Iluk postulował, by nauczać słownictwa w sposób zintegrowany. Im uczeń bardziej zaawansowany w nauce języka obcego, tym ważniejsze, by sprawdzać takie aspekty opanowania przez niego słownictwa jak różnorodność, trafność, adekwatne użycie słowa do sytuacji. Ponadto autor zwracał uwagę na to, jak ważne jest aktywowanie wiedzy, którą uczniowie już posiadają i odwoływanie się do ich doświadczeń przy wprowadzaniu nowego materiału leksykalnego. Ludzki mózg uczy się dopasowując nowe wiadomości do tych, które już posiada, dlatego bazowanie na wiedzy leksykalnej, którą uczniowie już opanowali, jest wskazanym podejściem przy nauczaniu słownictwa. Na ten czynnik zwraca uwagę także Kubiczek (2012: 82n.): „[...] coraz silniej podkreśla się konieczność wspierania naturalnego przebiegu procesów poznawania i zachowywania w pamięci słownictwa, a więc samodzielnego konstruowania znaczeń nowych wyrażeń i ich integrowania z indywidualnym systemem wiedzy uczącego się, tak by ten był zdolny rozumieć myśli i potrzeby innych oraz wyrażać własne intencje, używając struktury leksykalne stosownie do osoby rozmówcy i kontekstu sytuacyjnego". Aby umieć zastosować słownictwo odpowiednio do sytuacji, ważne jest, by uczeń mógł przećwiczyć wcześniej nowe słowa i wyrażenia w różnych kontekstach. Warto poprosić studenta /ucznia, by prześledził w słownikach jedno i dwujęzycznych, w jakich kontekstach pojawia się określone słowo, a następnie by stworzył podobne zdania, jednak odnosząc je do własnych doświadczeń.

Iluk (1995: 18n.) podkreślał także, by nauczyciele po zapoznaniu uczniów ze strategiami i technikami uczenia się i memoryzacji przetestowali je z uczniami na przykładowych ćwiczeniach. Mnemotechniki „pozwalające na trwalsze zapamiętywanie materiału leksykalnego" (Biedroń, 2009: 37) są bardzo istotne podczas przyswajania słownictwa, zwłaszcza, że nauka nowych słów polega nie tylko na wyuczeniu się ich znaczeń, lecz także ich wymowy, gramatyki i reguł ich użycia (zob. Andrzejewska 2004). Opanowanie słownictwa z jego kompleksowością staje się łatwiejsze, gdy uczniowie znają takie mnemotechniki jak wizualizacje rzeczywiste i wyobrażeniowe, akronimy, rymy, kategoryzacje itd. (Bohn, 1999).

Przetwarzanie słów jest skomplikowanym procesem, którego nie można analizować bez odniesienia do percepcyjnych i motorycznych funkcji mózgu 
(Legutko-Marszałek, 2013: 26-30). Uzasadnione wydaje się zatem podejście Macedonii, lingwistki badającej funkcjonowanie mózgu podczas nauki języków obcych, która propaguje uczenie się słownictwa poprzez ruch (VMI - Voice Movement Icons) (Macedonia, 2013). Zaletą jej metody jest szybkie przyswajanie nowych słów i wyrażeń, ponieważ przypisane im są określone ruchy. Trudność stanowi wydobywanie tych słów, bowiem wymaga ono od uczących się wykonania określonych ruchów, co w sytuacji komunikacyjnej, jak można przypuszczać, nie powinno mieć miejsca. Zgadzam się jednak z tym, że ruch wpływa w dużym stopniu na zapamiętywanie słowa, także podczas pisania. Przepisywanie słów i całych tekstów uważam także za ciekawy sposób na naukę słownictwa, nie tylko pisowni. Łatwiejsze zapamiętywanie własnoręcznie przepisanego tekstu wynika także z faktu, że charakter pisma jest osobowy i cechuje go duża rozpoznawalność (Neveling, 204: 199), a więc uczenie się w ten sposób bazuje na elemencie dobrze znanym użytkownikowi języka.

Również emocje odgrywają podczas nauki słownictwa niebagatelną rolę: „zapamiętywaniu sprzyjają emocje doznawane w czasie nauki. Pobudzanie ciała migdałowatego potęguje siłę zapisu pamięciowego, wzbogacając wspomnienie o wymiar emocjonalny" (Biedroń, 2009: 37). Mając tę wiedzę, musimy zdawać sobie sprawę z tego, że stworzenie życzliwej atmosfery na zajęciach będzie miało korzystny wpływ i na zapamiętywanie, i na motywację, a ta z kolei na chęć do nauki słownictwa, która wymaga przecież od ucznia licznych powtórek i długotrwałego zaangażowania.

\section{Badanie na temat technik uczenia się słownictwa}

\subsection{Pytania badawcze}

Celem badania ankietowego było uzyskanie odpowiedzi na pytania, w jaki sposób studenci uczą się słownictwa oraz czy znają techniki wspomagające efektywne uczenie się nowych słów. W kręgu zainteresowań autorki było także podejście nauczycieli na różnych etapach edukacyjnych do tej kwestii. Przede wszystkim autorka chciała zbadać, czy studenci (także wcześniej jako uczniowie) zostali zapoznani z technikami uczenia się słownictwa i czy przetestowali je na zajęciach, tak by uczący się mogli wybrać dla siebie najkorzystniejsze sposoby przyswajania materiału leksykalnego.

\subsection{Przebieg badania}

Ankieta została przeprowadzona wśród 71 studentów lingwistyki stosowanej w listopadzie 2014 roku w Poznaniu. Większość badanych stanowili studenci 
pierwszego roku studiów licencjackich (73\%), pozostali byli studentami drugiego roku. Wszyscy badani posługują się co najmniej dwoma językami i uczą się języka niemieckiego i angielskiego. 40 osób uczyło się lub obecnie uczy się trzeciego lub kolejnego języka obcego (fiński, islandzki, japoński, rosyjski, francuski, hiszpański, włoski, chiński). $60 \%$ badanych posiada średniozaawansowaną lub biegłą znajomość co najmniej jednego języka obcego. Większość osób uczyła się języków w szkole lub na kursie w szkole językowej oraz na studiach.

W dalszej części artykułu przedstawię analizę wyników odnoszących się do następujących pytań: Czy na zajęciach z języka obcego spotkałeś się z technikami ułatwiającymi naukę słownictwa? Czy nauczyciel przećwiczył z grupą techniki uczenia się nowych słów? Jaką technikę stosujesz podczas nauki słownictwa? W jaki sposób powtarzasz słówka? Czy uważasz, że możesz uczyć się słownictwa efektywniej?

\subsection{Wyniki}

Niemal 1/3 badanych przyznała, że nauczający języka obcego nie wprowadził na zajęciach technik efektywnego uczenia się słownictwa. Choć niewiele ponad połowa badanych spotkała się z opisem różnych sposobów optymalizacji nauki nowego materiału leksykalnego, to $82 \%$ nie przećwiczyło poznanych technik na zajęciach z nauczycielem.

Na pytanie, jak studenci uczą się słówek, trudno wskazać na dominującą technikę, badani wymieniali jedną, dwie lub co najwyżej trzy techniki. Niektórzy tworzą zdania, inni uczą się za pomocą fiszek, jeszcze inni wypisują nowe słowa i szukają skojarzeń (wszystkie wymienione techniki wskazało kilkanaście procent badanych). Niewiele osób korzysta z odsłuchów lub szuka tekstów z nowymi słowami (ok. 7\%). Tylko jedna osoba ćwiczy nowe słowa prowadząc konwersacje. Dopiero, gdy pojawiają się trudności, studenci korzystają z innych technik. Większość uczy się poprzez skojarzenia, bo aż 90\%. Kilka osób (8) wizualizuje sobie słowo, rysując obrazek, tworzy historię z użyciem nowym słów (11), grupuje wyrazy tematycznie (12), czy tworzy akronimy (4). Ok. 1/3 badanych tworzy zdania z nowym słowem, szuka synonimów i antonimów, wyobraża sobie, co przedstawiają dane słowa.

Najczęściej używane techniki przy powtarzaniu słów to czytanie ich na głos (63\%) i kilkukrotne pisanie ich (45\%).

Na pytanie, czy studenci sądzą, że są w stanie uczyć się efektywniej, $75 \%$ badanych odpowiedziało twierdząco, 20\% nie wie, pozostali udzielili negatywnej odpowiedzi. Studenci, którzy dostrzegają możliwość efektywniej- 
szego uczenia się słówek niż dotychczas, byli zdania, że stosując więcej różnorodnych technik łatwiej i na dłużej zapamiętywaliby nowe słowa, a nauka byłaby urozmaicona.

\section{Konkluzje}

1. Aby uczniowie mogli $w$ większym stopniu przetwarzać słownictwo i dzięki temu lepiej je zapamiętać, ważne jest, aby nauczyciel przećwiczył z nimi różne sposoby uczenia się. Wówczas będą mogli wypróbować i wybrać odpowiednią dla siebie technikę.

2. Istotną kwestią jest także wytłumaczenie uczniom/studentom, jak działa leksykon mentalny i czemu służą poszczególne techniki.

3. Warto byłoby zastanowić się także nad tym, jak zoptymalizować przepływ informacji między naukowcami a dydaktykami w tym zakresie.

4. Przypominanie o technikach uczenia się słownictwa na każdym etapie edukacyjnym przyniosłoby wymierne korzyści uczącym się.

\section{BIBLIOGRAFIA}

Andrzejewska, E. 2004. «Eigene Lernwege von Kindern beim Wortschatzerwerb im grundschulischen Fremdsprachenunterricht - Untersuchung zu Lernstrategien» (w) Sprachen lehren - Sprachen lernen. Nauczanie i uczenie się języków obcych. (red. C. Badstübner-Kizik, R. Rozalowska-Żądło, A. Uniszewska). Gdańsk: Wydawnictwo Uniwersytetu Gdańskiego: 176-189.

Baron-Cohen, S. i in. 2011. "Savant Memory in a Man with Colour Form Number Synaesthesia and Asperger Syndrome». Journal of Consciousness Studies 14, No. 9-10: 237-251.

Bethge, Ph. 2009. «Who Needs Berlitz? British Savant Learns German in a Week». Spiegel online: http://www.spiegel.de/international/germany/who-needs-berlitz-br itish-savant-learns-german-in-a-week-a-611381.html DW 20.07.2014.

Biedroń, A. 2009. «Czy neurologia ma zastosowanie w dydaktyce nauczania języków obcych?» (w) Problemy wspótczesnej dydaktyki języków obcych (red. M. Pawlak, M. Derenowski, B. Wolski). Poznań: Wydział Pedagogiczno-Artystyczny UAM: 29-38.

Bohn, R. 1999. Probleme der Wortschatzarbeit. Berlin, München: Langenscheidt.

Byrne, J. H. «Learning and Memory» Online: http://neuroscience.uth.tmc.edu/s4/chapter07.html DW 18.07.2014.

Collins, A. M., Loftus, E. F. 1975. «A Spreading-Activation Theory of Semantic Processing». Psychological Review 82: 407-428.

Czerniawska, E. 2003. «Nadzwyczajna pamięć (cz. 2). Pamięć, która nie przestaje zadziwiać - przypadek Szereszewskiego». Nowiny Psychologiczne 2/2003: 71-85. 
Deese, J. 1959. «On the prediction of occurrence of particular verbal intrusions in immediate recall». Journal of experimental psychology 58(1): 17-22.

De Groot, A. M. B. 1993. "Word-type effects in bilingual processing tasks: Support for a mixed-representational system» (w) The Bilingual Lexikon (red. R. Schreuder, B. Weltens). Amsterdam: John Benjamins: 27-51.

Dong, Y., Gui, S., MacWinney, B. 2005. "Shared and separate meaning in the bilingual mental lexicon». Bilingualism: Language and Cognition 8: 221-238.

Gajos, M. 2010. Podsystemy języka w praktyce glottodydaktycznej. Łódź: Wydawnictwo Uniwersytetu Łódzkiego.

Gasparov, B. 2010. Speech, Memory, and Meaning: Intertextuality in Everyday Language. Berlin, New York: De Gruyter Mouton.

Handke, J. 1997. "Zugriffsmechanismen im mentalen und maschinellen Lexikon». Kognitive Linguistik und Fremdsprachenerwerb: Das Mentale Lexikon (red. W. Boerner, K. Vogel). Tübingen: Narr: 89-106.

Hulstijn, J. H. 1997. "Mnemonic methods in foreign language vocabulary learning: Theoretical considerations and pedagogical implications» (w) Second Language Vocabulary Acquisition. A Rationale for Pedagogy (red. J. Coady, T. Huckin). Cambridge: CUP: 203-224.

Huneke, H.-W., Steinig, W. 2002. Deutsch als Fremdsprache. Eine Einführung. 3. überarbeitete und erweiterte Auflage. Berlin: Schmidt.

Iluk, J. 1995. «Curriculare Entscheidungen zur Wortschatzarbeit in den Lehrplänen». (w) Aspekte der Wortschatzbeschreibung für Zwecke des Fremdsprachenunterrichts (red. J. Iluk). Katowice: Wydawnictwo Uniwersytetu Śląskiego: 7-21.

Klippel, F. 1995. "Wörternetze» (w) Erwerb und Vermittlung von Wortschatz im Fremdsprachenunterricht. Arbeitspapiere der 15. Frühjahrskonferenz zur Erforschung des Fremdsprachenunterrichts. (red. K.-R. Bausch, H. Christ, H.-J. Krumm). Tübingen: Narr: 101-107.

Kubiczek, A. 2012. «Fazy przetwarzania informacji językowych w nauce obcojęzycznego słownictwa». Neofilolog 39/1: 81-93.

Kurcz, I. 2000. Psychologia języka i komunikacji. Wykłady z psychologii. Warszawa: Wydawnictwo „Scholar".

Legutko-Marszałek, I. 2013. "Kortikale und subkortikale Sprachareale im Lichte der neurokognitiven Sprachverarbeitungsmodelle». Glottodidactica XL/2: 21-33.

Lutjeharms, M. 2004. «Der Zugriff auf das mentale Lexikon und der Wortschatzerwerb in der Fremdsprache». Fremdsprachen Lehren und Lernen (FLuL) 33: 10-26.

Macedonia, M. 2013. „Fremdsprachen lernen mit Bewegung: Wie man natürlich und effizient lernt" (w) Mehrsprachigkeit grenzüberschreitend: Modelle, Konzepte, Erfahrungen (red. G. Gombos). Klagenfurt: Drava Verlag: 115-130.

Michońska-Stadnik, A. 2008. "The effect of internal manipulation of environmental context imagery on vocabulary recall in English» (w) Perspektywy glottodydaktyki i językoznawstwa. Tom jubileuszowy z okazji 70. urodzin Profesora Waldemara Pfeiffera (red. K. Myczko, B. Skowronek, W. Zabrocki). Poznań: Wydawnictwo UAM: 254-174. 
Müller, H. M. 2003. «Neurobiologische Aspekte des Fremdsprachenlernens» (w) Fremdsprachenlehren und Lernen 32. Jahrgang (red. G. Henrici, F. G. Königs, E. Zöfgen). Tübingen: Gunter Narr Verlag: 167-177.

Nation, P. 1993. "Vocabulary size, growth, and use» (w) The Biligual Lexicon (red. R. Schreuder, B. Weltens). Amsterdam: John Benjamins: 115-156.

Neveling, Ch. 2010. «Mentales Lexikon» (w) Metzler Lexikon (red. C. Surkamp). Stuttgart, Weimar: Metzler Verlag: 217-218.

Roediger, H. L., McDermott, K. B. 1995. «Creating false memories: Remembering words not presented in lists». Journal of Experimental Psychology: Learning, Memory, and Cognition 21 (4): 803-814.

Paradis, M. 2004. A Neuroliguistic Theory of Bilngualism. Amsterdam: John Benjamins.

Roche, J. 2008. Fremdsprachenerwerb. Fremdsprachendidaktik. 2. Auflage. Tübingen: Francke.

Rosch, E. 1978. «Prinicples of categorization» (w) Cognition and Categorization (red. E. Rosch, B. B. Lloyd). Hillsdale, NJ; NY: Lawrence Erlbaum: 27-48.

Smith, E. E., Shoben, E. J., Rips, L. J. 1974. «Structure and process in semantic memory: A featural model for semantic decisions». Psychological Review 81: 214-241.

Sökmen, A. J. 1997. "Current trends in teaching second language vocabulary» (w) Vocabulary: Description, Acquisition (red. N. Schmitt, M. McCarthy). Cambridge: CUP: 237-257.

Stork, A. 2003. Vokabellernen. Eine Untersuchung zur Effizienz von Vokabellernstrategien. Tübingen: Narr.

Targońska, J. 2011a. «Lexikalische Kompetenz - ein Plädoyer für eine breitere Auffassung des Begriffs». Glottodidactica XXXVII: 117-127.

Targońska, J. 2011b. «Słabo rozwinięta kompetencja leksykalna dorosłych - przyczyny, skutki i możliwości jej poprawy». Neofilolog 37: 55-71. 